Jurnal Health Sains: p-ISSN: 2723-4339 e-ISSN: 2548-1398

Vol. 2, No. 6, Juni 2021

\title{
PENGARUH MODEL PENDAMPINGAN DAN KARTU KENDALI FAKTOR RISIKO LUKA KAKI DIABETIK TERHADAP PRAKTIK PERAWATAN KAKI
}

\author{
Wahyu Widagdo \\ Politeknik Kesehatan Kemenkes Jakarta I, Indonesia \\ Email: dagdowi @yahoo.co.id
}

\begin{tabular}{ll}
\hline ARTIKEL INFO & ABSTRACT \\
\hline Diterima: 5 Juni 2021 & Diabetes mellitus can affect all organs of the body and cause \\
Direvisi: 15 Juni 2021 & various kinds of complaints with very varied symptoms. The \\
Disetujui: 25 Juni 2021 & purpose of the study was to analyze the effect of family \\
\hline Keywords: & assistance models \& diabetic foot risk factor control cards on \\
effect offamily assistance; & foot care practices in type 2 diabetes mellitus clients. The time \\
control cards for diabetic foot & of the research will take place in July to October 2019 The \\
riskfactors & population in this study people who suffer from DM inthe \\
& Pasar Minggu sub-district area with a large sample in \\
& accordance with the formula for calculating the number of \\
& samples and sampling techniques with purposive sampling \\
& technique. The results of the study showed a significant \\
& association of assistance with diabetic foot care practices $p$ \\
& $=0.003$ and a significant relationship between diabetic foot \\
& risk factor control cards with DM foot care practices $p=$ \\
& 0.000. An increase in the mean value of the mean pre and \\
posttest DM foot care practice in the intervention group and & the control group. T test results, the mean posttest of the \\
& intervention group was higher than the control group with a \\
& p value $=0,000$. Recommendations for assistance with clients \\
who have a high risk of diabetic injury. And the need to be \\
socialized and implemented a risk factor control card for \\
diabetic legs.
\end{tabular}

\begin{abstract}
ABSTRAK
Diabetes mellitus dapat mengenai semua organ tubuh dan menimbulkan berbagai macam keluhan dengan gejala yang sangat bervariasi. Tujuan dari penelitian adalah untuk menganalisis pengaruh model pendampingan keluarga \& kartu kendali faktor risiko kaki diabetic terhadap praktik perawatan kaki pada klien diabetes mellitus tipe 2. Lokasi penelitian di wilayah kerja Puskesmas Pasar Minggu Jakarta Selatan. Waktu pelaksanaan penelitian akan belangsung pada bulan juli s/d Oktober 2019 Populasi dalam penelitian ini masyarakat yang menderita DM di wilayah kecamatan Pasar Minggu dengan besar sampel sesuai dengan rumus penghitungan jumlah sampel dan teknik pengambilan sampel dengan teknik purposive sampling. Hasil Penelitian adanya hubungan bermakna pendampingan dengan praktik perawatan kaki diabetik $\mathrm{p}=0.003$ dan hubungan bermakna

kartu kendali factor risiko kaki diabetic dengan praktik
\end{abstract}

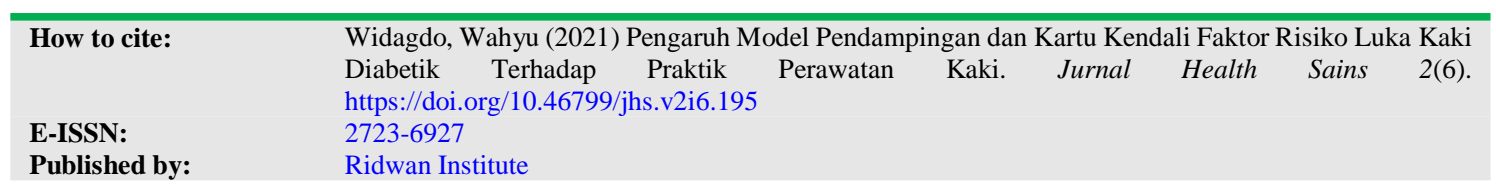


perawatan kaki DM $\mathrm{p}=0.000$. Adanya peningkatan nilai rerata rerata mean pre dan posttest praktik perawatan kaki DM pada kelompok intervensi dan kelompok control. Hasil

Kata Kunci:

pengaruh pendampingan

keluarga; kartu kendali faktor

risiko kaki diabetik uji $\mathrm{T}$, posttest mean rerata kelompok intervensi lebih tinggi dari kelompok control dengan nilai $\mathrm{p}=0.000$. Rekomendasi agar perlu pendampingan pada klien yang memiliki risiko tinggi luka diabetic. Dan perlunya disosialisai dan diterapkan kartu kendali factor risiko kaki diabetic.

\section{Pendahuluan}

Permasalahan kesehatan masyarakat yang cukup besar dihadapi Indonesia adalah Penyakit Tidak Menular (PTM). Dimana terjadi pergeseran pola penyakit secara epidemiologi dari penyakit menular yang cenderung menurun ke penyakit tidak menular yang secara global meningkat di dunia dan secara nasional telah mendekati sepuluh besar penyakit penyebab kematian dan kasus terbanyak diantaranya adalah penyakit diabetes mellitus (DM) dan penyakitmetabolik (RI, 2016).

Hiperglikemia adalah suatu kondisi medik berupa peningkatan kadar glukosa dalam darah melebihi batas normal. Hiperglikemia merupakan salah satu tanda khas penyakit diabetes mellitus (DM), meskipun juga mungkin didapatkan pada beberapa keadaan yang lain (Soelistijo \& Mili, 2015). Diabetes mellitus merupakan adalah penyakit multikronik yang berhubungan dengan ketidaknormalan produksi insulin, ketidakmampuan penggunaan insulin atau keduanya (Wahyuni, 2016).

Berdasarkan penelitian epidemiologi menunjukkan adanya kecenderungan peningkatan angka insidensi dan prevalensi DM tipe-2 di berbagai penjuru dunia. Badan Kesehatan Dunia (WHO) memprediksi adanya peningkatan jumlah penyandang DM yang menjadi salah satu ancaman kesehatan global. WHO memprediksi kenaikan jumlah penyandang DM di Indonesia dari 8,4 jutapada tahun 2000 menjadi sekitar 21,3 juta pada tahun 2030. Laporan ini menunjukkan adanya peningkatan jumlah penyandang DM sebanyak 2-3 kali lipat pada tahun 2035. Sedangkan International Diabetes Federation (IDF) memprediksi adanya kenaikan jumlah penyandang DM di Indonesia dari 9,1 jutapada tahun 2014 menjadi 14,1 juta pada tahun 2035 (Soelistijo \& Mili, 2015).

Riset Kesehatan Dasar (Riskesdas) 2018 menunjukkan prevalensi Penyakit Tidak Menular (PTM) mengalami kenaikan yang cukup memprihatinkan dibandingkan dengan Riskesdas 2013 lalu. Berdasarkan pemeriksaan gula darah, penyakit diabetes melitus naik dari 6,9 persen pada Riskesdas 2013 menjadi 8,5 persen di 2018. Sedangkan menurut konsesus Perkeni 2015 prevelensi DM 10,9 persen pada tahun 2018. Berdasarkan jenis kelamin prevalensi DM tahun 2018 menunjukkan perempuan lebih tinggi sebesar 1,8\% dibandingkan laki-laki sebesar 1,2\%. Prevalensi penduduk perkotaan lebih besar sebesar $1,5 \%$ dibandingkan pendudukan pedesaan sebesar $1,0 \%$. Berdasarkan kelompok usia prevalensi tertinggi sebesar 6,3 $\%$ pada usia $55-64$ tahun (RI, 2020).

Diabetes mellitus dapat mengenaisemua organ tubuh dan menimbulkan berbagai macam keluhan dengan gejala yang sangat bervariasi. Jika dibiarkan tidak dikelola dengan baik dapat menimbulkan berbagai komplikasi baik secara akut maupun kronik (Waspadji, 2007). Salah satukomplikasi umum dari diabetes mellitus adalah masalah kaki diabetes mellitus. Kaki diabetes yang tidak dirawat dengan baik akan mudah mengalami luka dan cepat 
berkembang menjadi ulkus kaki (Chapman et al., 2017). Sekitar $15 \%$ klien diabetes mellitus dalam perjalanan penyakit mengalami komplikasi ulkus diabetes terutama ulkus di kaki.

Masalah kaki diabetik yang rumit dengan berbagai pengobatan yang sering memakan waktu dan biaya yang besar, memberi dorongan bagi kita semua usaha rarus dilakukan untuk mencegah terjadinya kaki diabetik. Orang yang mengidap penyakit diabtes mellitus lebih tinggi risikonya mengalami masalah kaki karena berkurangnya sensasi nyeri setempat (neuropati) sehingga membuat klien tidak menyadari dan sering mengabaikan luka yangterjadi. Sirkulasi darah pada tungkai yang menurun dan terjadinya kerusakan endotel pembuluh darah berperan terhadap timbulnya kaki diabetek dengan menurunnya jumlah oksigen dan nutrisi yang disuplai ke kulit maupun jaringan lain, sehingga menyebabkan luka tidak sembuhsembuh. Berkurangnyadaya tahan tubuh yang terjadi pada klien diabetes mellitus juga rentan terhadap infeksi. Kuman pada luka akan berkembang cepat ke seluruh tubuh melalui aliran darah yang bias berakibat fatal, yang disebut dengan sepsis(Chapman et al., 2017).

Salah satu factor risiko timbulnya ulkus pada kaki klien diabetes mellitus adalah perilaku maladaptive yaitu kurang patuh dalam melakukan pencegahan luka, pemeriksaan kaki, memelihara kebersihan, kurang melaksanakan pengobatan, aktifitas yang tidak sesuai, serta kelebihan beban pada kaki (Lipsky et al., 2014). Upaya pencegahan primer pada pengelolaan kaki diabetic yang bertujuan untuk mencegah luka kaki secara dini penting sekali untuk menghidarkan kerusakan lebih lanjut dan tidak timbul ulkus yang dapat mengakibatkan tindakan amputasi. Infeksi atau luka kecil harus ditangani dengan serius. Sepatu yang tidak pas harus cepat diganti karena menimbulkan luka (Edmonds et al., 2010).
Menjaga agar gula darah tetap dalam batas normal dan mencegah agar tidak terjadi ulkus adalah hal yang sangat penting. Ini tegantung pada motivasi klien untuk mengenal penyakitnya. Pengetahuan seseorang erat kaitnya dengan perilaku yang akan diambilnya, karena dengan pengetahuan tersebut klien memiliki alasan dan landasan untuk menentukan suatu pilihan. Dengan pengetahuan manusia dapat mengembangkan apa yang diketahui dan dapat mengatasi kebutuhan kelangsungan hidup, sehingga akan mempengaruhi seseorang dalam berperilaku. Terbentuknya suatu perilaku baru terutama pada orang dewasa dimulai pada domain kognitif dalam arti subjek tahu terlebih dahulu terhadap stimulus yang berupamateri atau objek diluarnya. Sehingga menimbulkan pengetahuan baru dan akan terbentuk dalam sikap maupun tindakan (Shearman et al., 2015).

Pentingnya klien DM mengetahui cara mencegah timbulnya ulkus pada kaki sehingga kejadian ulkus amputase dapat dihindari. Klien diabetes mellitus harus rajin merawat dan memeriksa kaki untuk menghindaroi terjadinya kaki diabetic dan kecacatan yang mungkin akan timbul. Peningkatan pengetahuan klien diabetes mellitus mengenai cara mencegah kaki diabetic yang dapat meningkatkan kualitas hidup klien diabetes sehingga klien dapat menikmati hidup secara normal pada umumnya yang tidak menederita diabetes mellitus, serta klien tidak perlu mengeluarkan uang secara berlebihan untuk pengobatan yang seharusnya tidak diperlukan.

Selama ini perawat telah melakukan beberapa intervensi keperawatan untuk mencegah terjadinya luka kaki diabetic. Salah satu intervensi yang dilakukan adalah melakukan edukasi atau pengajaran tentang perawatan kaki diabetik (McEwen \& Nies, 2018). Pengajaran ini dapat dilakukan secara individual atau hanya pada klien saja atau bias melibatkan orang dekat klien yang dapat 
membantu klien dalam mengimplementasi pengajaran perawatan kaki yang diterimanya dari perawat (Sari et al., 2016).

Pendekatan lain yang bisa dilakukan untuk meningkatan kemampuan klien untuk mencegah terjadinya luka kaki diabetic, yaitu melalui pendampingan keluarga. Pendampingan keluarga merupakan suatu pendekatan melalui proses kolaborasi yang berfokus pada solusi, berorentasi pada hasil dan sistematis, dimana pendamping atau perawat memfasilitasi peningkatan atas performan kerja, pengalaman hidup, pembelajaran diri dan pengembangan klien yang memungkinkan bisa mencegah kaki diabetic sebagai salah satu masalah (Vitorino et al., 2011).

Upaya peningkatan kemampuan klien dalam merawat kaki diabetic, perlu didukung alat yang dapat mengingatkan aspek apa yang harus dimonitor pada kaki yang menderita DM. alat tersebut berupa kartu. Kartu yang dimaksud tersebut adalah kartu kendali factor risiko luka kaki diabetic. Melalui kartu tersebut diharapkan klien secara teratur dapat memantau kondisi kaki, sehingga bahaya terjadi luka kaki diabetic dapat dihindari. Dengan demikian akan menurunkan angka kasus amputasi akibat luka kaki diabetik (McEwen \& Nies, 2018).

Tujuan penelitian adalah untuk menganalisis pengaruh model pendampingan keluarga dan kartu kendali factor risiko kaki diabetik terhadap praktik perawatan kaki pada klien diabetes mellitus di wilayah kerja Puskesmas Pasar Minggu Jakarta Selatan.

Manfaat penelitian adalah untuk menumbuhkan kondisi lingkungan civitas akademica untuk berkarya ilmiah melalui kegiatan penelitian dan meningkatkan kinerja institusi melalui kegiatan penelitian bidang keilmuan keperawatan komunitas.

\section{Metode Penelitian}

Desain penelitian yang digunakan pada penelitian ini adalah desain kuasi eksperimen yang bertujuan untuk melihat pengaruh program pengajaran perawatan kaki dalam kontek keluarga model terhadap praktik perawatan kaki pada klien DM tipe 2 .

Identifikasi klien yang memilki yang didiagnosis Diabetes Mellitus tipe 2 berdasarkan data yang diperoleh pada pengunjung Posbindu PTM di wilayah Kecamatan Pasar Minggu sebagai kelompok intervensi, setelah itu dilakukan kunjungan rumah untuk melakukan program pengajaran perawatan kaki kelompok intervensi. Sebelumnya dilakukan pretest pada kelompok intervensi dan kelompok kontrol dengan menggunakan metode wawancara menggunakan kuesioner. Selanjutnya dilakukan intervensi program pengajaran perawatan luka dengan pendekatan keluarga selama 4 minggu. Pada minggu I peneliti melakukan identifikasi perawatan kaki yang telah dilakukan dan memberikan perawatan kaki dengan cara melibatkan keluarga meliputi faktor resiko komplikasi kaki, cara membersihkan kaki, dan perawatan kuku dengan menggunakan media berupa modul. Minggu II, pencliti memberikan edukasi lanjutan tentang pemilihan alas kaki, pencegahan dan pengelolaan cedera pada kaki kepada responden dan keluarga. Minggu III, peneliti melakukan tindak lanjut intervensi kepada responden melalui telpon kepada keluarga dengan melakukan idenitikasi perilaku perawatan sesuai kriteria kaki yang sudah dilakukan serta mengingatkan kepada pasien dan keluarga tentang materi edukasi perawstan kaki yang telah diberikan. Minggu IV dan Minggu $\mathrm{V}$ peneliti berkunjung melakukan tatap muka dengan pasien dan keluarga. Melakukan identikasi tentang perawatan kaki yang dijalankan klien. berdasarkan mengidentiikasi kesulitan yang dihadapi oleh pasien dalam menjalankan atau serta melakukan observasi pada kebersihan perawatan kaki, perawatan kuku kaki dan pemilihan alas kaki. Minggu VI. peneliti melakukan evaluasi kembali tentang 
perawatan kaki dan kebersihan kaki, perawatan kuku kaki dan pemilihan alas kaki. Setclah itu peneliti melakukan post test dengan menggunakan kuesioner yang samapada saat pre test.

Penelitian ini dilakukan juga menggunakan pre test and post test disignwith control group suatu pengukuran hanya dilakukan pada sebelum dan akhir intervensi. Pre test dilakukan pada kelompok intervensi dan kelompok kontrol untuk mengetahui data dasar yang akan digunakan untuk mengetahui efek variabel independen. Post test dilakukan pada kelompok intervensi dan kelompok kontrol setelah dilakukan perlakuan. Hasil pengukuran dari dua kelompok tersebut dibandingkan. Rentang pre dan post test adalah 30 hari. Hal ini sesuai dengan teori evaluasi bahwa jarak antara pengukuran minimal 2 (dua) minggu untuk pengetahuan dan minimal 1 bulan untuk perilaku (Budiharto et al., 2008).

Teknik pengambilan sampel dilakukan dengan cara stematic sampling yaitu merekrut subjek yang memenuhi kriteria inklusi. Menentukan besar sampel dari dua kelompok indipenden dengan uji hipotesis untuk mean 2 populasi (satu sisi) menggunakan rumus menurut Sastroasmoro (Supriyatno et al., 2010).

\section{Hasil dan Pembahasan}

\section{A. Hasil Penelitian}

1. Distribusi frekuensi

Pada Bab IV ini akan memaparkan hasil penelitian tentang pengaruh model pendampingan keluarga dan kartu kendali factor risiko kaki diabetic terhadap praktik perawatan kaki pada klien diabetes mellitus tipe 2 di wilayah kerja Puskesmas Kecamatan Pasar Minggu Jakarta Selatan, yang telah dilakukan pada bulan Agustus s/d Oktober 2019. Dalam penelitian ini jumlah subjek dalam penelitian ini sebanyak 60 responden, 30 responden kelompok intervensi dan 30 responden kelompok kontrol. Responden dipilih berdasarkan kriteria inklusi yang sudah ditetapkan, data diambil sebelum dan setelah dilakukan intervensi. Pengambilan data dilakukan di rumah klien yang berada di wilayah Puskesmas KecamatanPasar Minggu. Data yang diperoleh dianalisis bivariat, dan multivariat dengan menggunakan SPSS, dengan hasil sebagai berikut:

\section{Tabel 1}

Distribusi Responden Berdasarkan Jenis Kelamin, Umur, Status

Perkawinan, Tingkat Pendidikan,

Pekerjaan, Pendampingan, Kartu

Kendali Dan Praktik Pengendalian

Factor Risiko Setelah Perlakuan

Pada Kelompok Intervensi Dan Kelompok Control Di Wilayah

Puskesmas Pasar Minggu Jakarta Selatan 2019

\begin{tabular}{|c|c|c|c|c|c|c|}
\hline \multirow[t]{2}{*}{ Variabe } & \multicolumn{2}{|c|}{$\begin{array}{l}\text { Kelompok } \\
\text { intervensi }\end{array}$} & \multicolumn{2}{|c|}{$\begin{array}{c}\text { Kelompok } \\
\text { kontrol }\end{array}$} & \multicolumn{2}{|c|}{$\underline{\text { Jumlah }}$} \\
\hline & f & $\%$ & f & $\%$ & $\mathbf{F}$ & $\%$ \\
\hline Muda & 14 & $4 \overline{46,7}$ & 16 & 53,3 & 30 & $\underline{50}$ \\
\hline Tua & 16 & $\underline{53,3}$ & 14 & 46,7 & $\underline{30}$ & $\underline{50}$ \\
\hline Laki-laki & 10 & 33.3 & 9 & 30.0 & 19 & $\underline{31,7}$ \\
\hline Perempua: & 20 & $\underline{66.7}$ & 21 & 70.0 & $\underline{41}$ & $\underline{68.3}$ \\
\hline Rendah & 18 & $\underline{60.0}$ & 22 & 73.3 & $\underline{40}$ & $\underline{66.7}$ \\
\hline Tinggi & 12 & 43.3 & 8 & 26.7 & 20 & 33.3 \\
\hline $\begin{array}{c}\text { Tidak } \\
\text { bekerja }\end{array}$ & 23 & 76.7 & 19 & 63.3 & 42 & 70.0 \\
\hline Bekerja & 7 & 23.3 & 11 & $\underline{36.7}$ & $\underline{18}$ & $\underline{30.0}$ \\
\hline Kurang & 4 & 13.3 & 8 & 26.7 & 12 & 20.0 \\
\hline Baik & 26 & $\underline{86.7}$ & 22 & 73.3 & $\underline{48}$ & $\underline{80.0}$ \\
\hline Tidak & 5 & 16.7 & 30 & 100.0 & 35 & 8.3 \\
\hline Didampingi & & & & & & \\
\hline Didamping & 25 & $\underline{83.3}$ & $\underline{0}$ & $\underline{0}$ & 25 & $\underline{91.6}$ \\
\hline $\begin{array}{c}\text { Tidak ada } \\
\text { kartu }\end{array}$ & 6 & 20.0 & 30 & 100.0 & 36 & 60.0 \\
\hline Kartu & 24 & $\underline{80.0}$ & $\underline{0}$ & $\underline{0}$ & 24 & $\underline{40.0}$ \\
\hline Tidak & 8 & 26.7 & 30 & 100.0 & 38 & 63.3 \\
\hline Mendukung & & & & & & \\
\hline Mendukun & 22 & $\underline{73.3}$ & $\underline{0}$ & $\underline{0}$ & $\underline{22}$ & $\underline{36,7}$ \\
\hline
\end{tabular}
distribusi umur responden pada kelompok intervensi sebagian besar adalah usia tua $(53,3 \%)$ sedangkan kelompok kontrol seimbang antara yaitu usia muda dan usia tua $(53,3 \%)$, 
sebagian besar responden baik dari kelompok intervensi $(66.7 \%)$ maupun kelompok kontrol $(70,0 \%)$ adalah perempuan. Sebagian besar responden pada kelompok intervensi $(60,0 \%)$ dan kelompok kontrol berpendidikan rendah $(56.7 \%)$.

Tabel di atas menunjukkan bahwa sebagian besar responden baik kelompok intervensi $(76.7 \%)$ maupun kelompok kontrol (63.3\%) tidakbekerja.

Pada tabel 1 juga menunjukkan bahwa sebagian besar responden baik kelompok intervensi (86.7\%) maupun kelompok kontrol (73.3\%) memiliki tingkat pengetahuan baik. Sebagian besar responden kelompok intervensi $(83.3 \%)$ mendapatkan pendampingan keluarga, sedangkan responden kelompok kontrol seluruhnya $(100 \%)$ tidak mendapat pendampingan keluarga. Responden kelompok intervensi (80\%) telah menggunakan kartu kendali factor risiko luka kaki diabetik. Sedangkan responden dari kelompok kontrol semuanya $(100 \%)$ tidak kartu kendali factor risiko luka kaki diabetik. Sebagian besar $(73.3 \%)$ responden kelompok intervensi mendukung dalam praktik pencegahan luka kaki diabetik, dan sedangkan pada kontrol seluruhnya tidak mendukung (100\%) dalam praktik perawatan kaki diabetik.

2. Analisis Bivariat

Analisis bivariat dilakukan untuk mengetahui:

a. Hubungan antara variabel umur, jenis kelamin, pendidikan, pekerjaan, pengetahuan, pendampingan keluarga) dan kartu sikap dengan praktik perawatan kaki diabetik. Untuk mengetahui hubungan antara variabel independent dengan dependent dilakukan dengan menggunakan uji statistik Chi-Square.

b. Ada tidaknya perbedaan praktik perawatan kaki diabetik sebelum dan sesudah perlakuan, ada tidaknya perbedaan praktik perawatan kaki diabetik sebelum dan setelah perlakuan pada kelompok kontrol, mengetahui perbedaan praktik perawatan kaki diabetik setelah perlakuan antara kelompok intervensi dan kelompok kontrol. Untuk mengetahui perbedaan praktik perawatan kaki diabetik pada kelompok intervensi, perbedaan pada kelompok kontrol dilakukan dengan menggunakan ujit berpasangan (paired $\mathrm{t}$ test).

Tabel 2

Distribusi responden menurut

Umur dan praktik perawatan kaki diabetik di wilayah Puskesmas Pasar Minggu Jakarta Selatan 2019

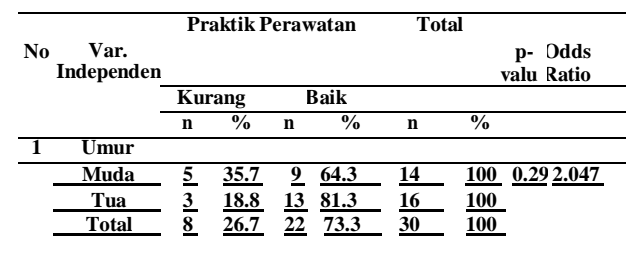

Hasil analisis hubungan antara umur dengan praktik perawatan kaki diabetik diperoleh bahwa semua 13 $(81.3 \%)$ responden yang berusia tua baik dalam praktik perawatan kaki diabetik. Sedangkan diantara responden yang berusia muda ada 9 (64.3\%) yang baik praktik perawatan kaki diabetik. Hasil uji statistik diperoleh nilai $\mathrm{p}=$ 0.295 maka dapat disimpulkan bahwa tidak ada perbedaan praktik perawatan kaki diabetik antara responden yang berusia tua dengan responden yang berusia muda. 


\section{Analisis Multivariat}

Untuk memperoleh jawaban faktor mana yang paling berpengaruh terhadap praktik perawatan kakidiabetic maka perlu dilakukan analisis multivariat dengan analisis regresi logistik. Tahapan analisis multvariat meliputi: pemilihan variabel kandidat multivariat, dan pemilihan variabel paling berpengaruh.

Tabel 3

Pemilihan Variabel Kandidat

Multivariat dari Variabel yang diduga berpengaruh dengan praktik pengendalian factor risiko PTM dengan nilai $p<0.25$

\begin{tabular}{llcl}
\hline No & \multicolumn{1}{c}{ Variabel } & p-value & OR \\
\hline 1 & Umur & 0.295 & 2.407 \\
\hline 2 & Jenis Kelamin & 0.559 & 0.583 \\
\hline 3 & Pendidikan & 0.866 & 1.154 \\
\hline 4 & Pekerjaan & 0.896 & 0.882 \\
\hline 5 & Pengetahuan & 0.019 & 12.600 \\
\hline 6 & $\begin{array}{l}\text { Pendampingan } \\
\text { Keluarga }\end{array}$ & 0.003 & 21.000 \\
7 & Kartu Kendali & 0.000 & 35.000 \\
\hline
\end{tabular}

Dari tabel di atas ternyata adatiga variabel yang diduga berpengaruh dengan $\mathrm{p}<0.25$, yaitu pengetahuan, pendampingan keluarga, dan kartu kendali factor risiko luka kaki diabetik. Setelah ditemukan ke tiga variabel tersebut, lalu dilakukan pemilihan variabel yang paling berpengaruh secara signifikan dengan praktik perawatan kaki diabetik.

\section{B. Pembahasan}

Berdasarkan hasil penelitian yang diperoleh pada Bab IV, selanjutnyapeneliti akan melakukan pembahasan hasil penelitian dibagi menjadi dua bagian pokok yaitu: pertama mengenai keterbatasan penelitian, dan ke dua mengenai pembahasan penelitan. Penelitian berkaitan dengan praktik perawatan kaki diabetik, dimana responden yang diambil dalam penelitian ini adalah masyarakat yang menderita DM yang memanfaatkan Puskesmas Pasar Minggu. Namun pada kenyataan selamaini tidak seluruh masyarakat yang menderita DM memanfaatkan fasilitas pelayanan kesehatan di wilayah Puskesmas Kecamatan Pasar Minggu. Jadiresponden yang diambil belum mewakili kondisi masyarakat di wilayah tersebut baik sebagai kelompok intervensi dankelompok kontrol. Beberapa masyarakat yang masuk dalam kriteria sebagai responden tidak semua bersedia sebagai responden, hal disebabkan dengan ketersediaan waktunya dan sudah sering menjadi responden mengingat peneliti melakukan beberapa kali kunjungan rumah untuk melakukan pungumpulan data dan melakukan intervensi untuk memberikan pendampingan kepada keluarga. Keterbatasan waktu sebagai responden, khususnya pada keluarga yang dilakukan pendampingan karena sibuk bekerja dan sulit mengatur waktu.

a. Umur

Berdasarkan hasil penelitian ini didapatkan gambaran bahwa sebagian besar responden berada pada usia tua (>55 tahun) yaitu sebanyak 16 responden $(53.3 \%)$. Beberapa hasil menunjukkan yang berbeda bahwa umur berhubungan dengan diabetes, hal dikemukan dari Penelitian Trisnawati menemukan bahwa ada hubungan yang signifikan antara umur dengan kejadian diabetes mellitus ( $p$ value $=0.006) \quad($ Trisnawati \& Setyorogo, 2013). Selain itu, studi yang dilakukan Sunjaya juga menemukan bahwa kelompok umur yang paling banyak menderita diabetes mellitus adalah kelompok umur 45-52 tahun (Sujaya, 2009). Mayoritas pasien memiliki diabetes tipe $2(96,75 \%)$ dengan usia rata-rata $57,30 \pm 10,47$ tahun (Assaad-Khalil et al., 2015). Hal serupa juga dikemukan dalam 
penelitian Fitria yang menyatakan bahwa penderita ulkus diabetikum banyak dialami klien yang berusia lansia akhir (usia 56 - 65 tahun)sebesar $45.6 \%$ (Fitria et al., 2017).

b. Jenis Kelamin

Responden yang berjenis kelamin perempuan pada kelompok intervensi sebanyak 14 orang $(66.7 \%)$ sedang yang berjenis kelamin perempuan pada kelompok kontrol 21 orang $(70.0 \%)$. Hal ini sesuai penelitian yang dilakukan pada umumnya responden klien kaki diabetic adalah perempuan $57.3 \%$, serta menurut penelitian Fitria responden perempuan sebesar 54.4\% (Fitria et al., 2017).

c. Pendidikan

Berdasarkan hasil penerlitian didapatkan pada responden kelompok intervensi sebagian besar berpendidikan rendah sebanyak 18 orang $(60.0 \%)$, begitu juga kelompok kontrol sebesar 22 orang $(73,3 \%)$ berpendidikan rendah. Secara teoritis menyatakan bahwa Pendidikan formal tinggi akan mempunyai pengetahuan yang lebih tinggi dibandingkan seseorang Pendidikan rendah (Notoatmodjo, 2012). Menurut penelitian Mpofu menunjukkan bahwa pendidikan rendah pada perempuan lebih cenderung untuk kurang melakukan aktifitas fisik, kurang mengkonsumsi buah dan sayur, merokok, mengkonsumsi obesitas dan melaporkan mengalami hipertensi ( $\mathrm{p}=0.010)$ (Mpofu, 2016).

d. Pekerjaan

Berdasarkan hasil penelitian, mayoritas responden adalah mereka yang tidak bekerja pada kelompok intervensi sebesar 23 orang (76.7\%) sedangkan untuk responden kelompok kontrol yang tidak bekerja sebesar 19 orang $(63,3 \%)$. Menurut pendapat
Notoadmodjo orang bekerja cendrung memiliki waktu sedikit untuk mengunjungi fasilitas kesehatan sehingga akan sedikit waktunya dan kesempatan untuk melakukan pemeliharaan kesehatan atau pengobatan (Notoatmodjo, 2010).

\section{Kesimpulan}

Berdasarkan karakteristik responden pada kelompok intervensi dan kelompok kontrol diperolehkan gambaran bahwa usia responden seimbang antara tua dan muda $(50 \%)$, sebagian besar berjenis kelamin perempuan (68.3\%), latar belakang pendidikan rendah $(66.7 \%)$, tidak bekerja (70\%) dan memiliki tingkah pengetahuan baik (80\%). Dari variabel yang ada diatas, hanya variabel pengetahuan yang menunjukkan hubungan bermakna terhadap praktik perawatan kaki diabetic dengan $p=0.019$. Pada responden kelompok intervensi yang mendapat pendampingan keluarga menunjukkan hubungan yang bermakna pendampingan keluarga dengan praktik perewatan kaki diabetic dengan $\mathrm{p}=0.003$. Sedangkan untuk responden yang mendapat kartu kendali juga menunjukkan hubungan yang bermakna antara kartu kendali factor risiko luka kaki diabetic dengan $\mathrm{p}=0.000$. Berdasarkan hasil mean rerata pre dan posttest praktik perawatan kaki diabetik pada kelompok intervensi menunjukkan adanya peningkatan dengan $\mathrm{p}=0.000$. Demikian juga hasil pre dan posttest praktik perawatan kaki diabetic pada kelompok control menunjukkan adanya peningkatan rerata mean dengan $\mathrm{p}=0.000$. Adanya peningkatan rerata mean posttest baik pada kelompok intervensi dan kelompok control dengan $\mathrm{p}=0.000$, namun terlihat adanya perbedaan untuk mean rerata antara kelompokintervensi dengan kelompok control, dimana nilai mean kelompok intervensi lebih tinggi dari nilai mean kelompok control. Hal ini menunjukkan bahwa pendampingan keluarga 
dan kartu kendali faktor risiko luka kaki diabetic memberikan pengaruh terhadap praktik klien dalam perawatan kaki diabetic.

\section{BIBLIOGRAFI}

Assaad-Khalil, S. H., Zaki, A., Rehim, A. A., Megallaa, M. H., Gaber, N., Gamal, H., \& Rohoma, K. H. (2015). Prevalence Of Diabetic Foot Disorders And Related Risk Factors Among Egyptian Subjects With Diabetes. Primary Care Diabetes, 9(4), 297-303. Google Scholar

Budiharto, T., Musat, E., Poortmans, P., Hurkmans, C., Monti, A., Bar-Deroma, R., Bernstein, Z., Van Tienhoven, G., Collette, L., \& Duclos, F. (2008). Profile Of European Radiotherapy Departments Contributing To The Eortc Radiation Oncology Group (Rog) In The 21st Century. Radiotherapy And Oncology, 88(3), 403-410. Google Scholar

Chapman, S., Marrochio, H., \& Myers, R. C. (2017). Complexity Of Formation In Holography. Journal Of High Energy Physics, 2017(1), 62. Google Scholar

Edmonds, E. V, Pavcnik, N., \& Topalova, P. (2010). Trade Adjustment And Human Capital Investments: Evidence From Indian Tariff Reform. American Economic Journal: Applied Economics, 2(4), 42-75. Google Scholar

Fitria, H., Mukhtar, M., \& Akbar, M. (2017). The Effect Of Organizational Structure And Leadership Style On Teacher Performance In Private Secondary School. Ijhcm (International Journal of Human Capital Management), 1(02), 101-112. Google Scholar

Lipsky, P. E., Calabrese, L. H., Kavanaugh, A., Sundy, J. S., Wright, D., Wolfson, M., \& Becker, M. A. (2014). Pegloticase Immunogenicity: The Relationship Between Efficacy And Antibody Development In Patients Treated For Refractory Chronic Gout. Arthritis Research \& Therapy, 16(2), 1-8.
Google Scholar

Mcewen, M., \& Nies, M. A. (2018). Unit 1 Introduction To Community Health Nursing. Community/Public Health Nursing-E-Book: Promoting The Health Of Populations, 1. Google Scholar

Mpofu, T. R. (2016). The Determinants Of Exchange Rate Volatility In South Africa. Economic Research Southern Africa, Working Paper, 604. Google Scholar

Notoatmodjo, S. (2010). Ilmu Perilaku Kesehatan. Penerbit Rineka Cipta. Google Scholar

Notoatmodjo, S. (2012). MetodologiPenelitian Kesehatan. Google Scholar

Ri, K. (2016). Kementerian Kesehatan Republik Indonesia. 2018. Pedoman Umum Gizi Seimbang. Jakarta (Id): Direktorat Jenderal Bina Kesehatan Masyarakat. Google Scholar

Ri, K. (2020). Pedoman Pencegahan Dan Pengendalian Coronavirus Disease (Covid-19)'. Kemenkes Ri, O-115. Google Scholar

Sari, C. W. M., Haroen, H., \& Nursiswati, N. (2016). Pengaruh Program Edukasi Perawatan Kaki Berbasis Keluarga Terhadap Perilaku Perawatan Kaki Pada Pasien Diabetes Melitus Tipe 2. Jurnal Keperawatan Padjadjaran, 4(3). Google Scholar

Shearman, J. R., Sangsrakru, D., Jomchai, N., Ruang-Areerate, P., Sonthirod, C., Naktang, C., Theerawattanasuk, K., Tragoonrung, S., \& Tangphatsornruang, S. (2015). Snp Identification From Rna Sequencing And Linkage Map Construction Of Rubber Tree For Anchoring The Draft Genome. Plos One, 10(4), E0121961. Google Scholar

Soelistijo, U. W., \& Mili, M. Z. (2015). Controlling And Curb Of Development: The Case Of National Management Of 
Indonesia Mineral Resources. Social Sciences, 4(1), 5-22. Google Scholar

Sujaya, D. (2009). Pembuatan Game Krazy Minigolf. Universitas KristenMaranatha. Google Scholar

Supriyatno, B., Said, M., Hermani, B., Sjarif, D. R., \& Sastroasmoro, S. (2010). Risk Factors Of Obstructive Sleep Apnea Syndrome In Obese Early Adolescents: A Prediction Model Using Scoring System. Paediatric RespiratoryReviews, 11(1), 1. Google Scholar

Trisnawati, S. K., \& Setyorogo, S. (2013). Faktor Risiko Kejadian Diabetes Melitus Tipe Ii Di Puskesmas Kecamatan Cengkareng Jakarta Barat Tahun 2012. Jurnal Ilmiah Kesehatan, 5(1), 6-11. Google Scholar
Vitorino, M. D., Christ, L. R., Barbieri, G., Cuda, J. P., \& Medal, J. C. (2011).

Calophya Terebinthifolii (Hemiptera: Calophyidae), A Candidate For Biological Control of Schinus Terebinthifolius (Sapindales: Anacardiaceae): Feeding Preferences And Impact Studies. Florida Entomologist, 94(3), 694-695. Google Scholar

Wahyuni, A. (2016). Senam Kaki Diabetik Efektif Meningkatkan Ankle Brachial Index Pasien Diabetes Melitus Tipe 2. Jurnal Ipteks Terapan, 9(2), 19-27. Google Scholar

Waspadji, S. (2007). Penatalaksanaan Dm Terpadu. Fakultas Kedokteran Universitas Indonesia, Jakarta. Google Scholar

Copyright holder:

Wahyu Widagdo (2021)

First publication right:

Jurnal Health Sains

This article is licensed under:

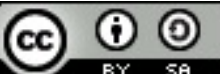

